Lisbon - Malacca Port Cities Twin Conferences 2019 / 2020

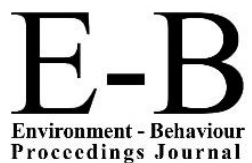

AicQoL2020Malacca

ASLI (Annual Serial Landmark International) Conferences on QoL2020

https://www.amerabra.org; https://fspu.uitm.edu.my/cebs; https://www.emasemasresources.com/

8th AMER International Conference on Quality of Life

Mahkota Hotel Melaka, Malacca, Malaysia, 18-19 Mar 2020

(Due to the Covid-19 lockdown, paper virtually presented on 25 Mar 2020)

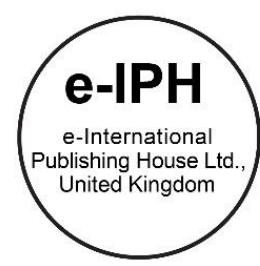

\title{
Nurturing Community Engagement in Coastal Erosion Risk Management in Kuala Selangor, Malaysia
}

\author{
Yusfida Ayu Abdullah, Habsah Hashim, Naásah Nasrudin, Puziah Ahmad \\ Centre of Studies for Town and Regional Planning, Responsive Environmental Development Research Interest Group, \\ Green Technology \& Sustainable Development CoRe UiTM (GTSD), Faculty of Architecture, Planning and Surveying, \\ Universiti Teknologi Mara (UiTM), Selangor, Malaysia.
}

ayunazeri@gmail.com, habsah99@yahoo.com, naasah76@gmail.com, puziah.ahmad114@gmail.com Tel: $+6018-3680243$

\begin{abstract}
The coastal areas in Peninsular Malaysia have been experiencing immense coastal erosion issues. The government executed many initiatives to reduce coastal erosion and damages. This study aims at examining the local community's beliefs and role in protecting their coastal areas. Pantai Jeram and Pantai Remis became the case study, and a questionnaire survey using purposive sampling was conducted involving 212 respondents. A focus group discussion was also operated. Results demonstrated severe damage to the coastal area and revealed the awareness of the residents and their willingness to participate in community engagement programs.
\end{abstract}

Keywords: Coastal Zone; Coastal Erosion; Coastal Risk Management; Community Engagement

eISSN: 2398-4287 @ 2020. The Authors. Published for AMER ABRA cE-Bs by e-International Publishing House, Ltd., UK. This is an open access article under the CC BYNC-ND license (http://creativecommons.org/licenses/by-nc-nd/4.0/). Peer-review under responsibility of AMER (Association of Malaysian Environment-Behaviour Researchers), ABRA (Association of Behavioural Researchers on Asians) and cE-Bs (Centre for Environment-Behaviour Studies), Faculty of Architecture, Planning \& Surveying, Universiti Teknologi MARA, Malaysia.

DOI: https://doi.org/10.21834/e-bpj.v5i13.2053

\subsection{Introduction}

Coastal zone is a zone of the land area influenced by the sea (i.e., the water body zone that exposed to the tidal cycle) and the land area that is controlled by the land (the coastal area that is affected by land development). The National Coastal Zone Physical Plan (2012a) defines the coastal zone as covering five (5) km inland and three (3) nautical miles inland from the tidal area. Coastal zone has high merit in socio-economic activities and is worth protecting due to its physical setting, which suits activities including aquaculture, human settlements, eco-tourism, and shipping. However, the coastal zones are continually facing the challenges of development pressures and hazards, either from natural events or human-made activities.

Coastal hazards are considered as essential management issues since they had resulted in evident environmental and social catastrophes (Haslett, 2009). Hashim et al. (2010) believed that coastal erosion is one of the most critical problems across the globe. It is apparent that, in Malaysia, human activities such as over-logging and clear-cutting of mangroves along coastal zones had resulted in the coastline to be exposed to hazards like tidal inundation, storm surges, currents and wave energy (Hashim et al., 2010). Van Rijn (2011) thought that human activities had intensified coastal erosion. Furthermore, because of these threats, the coastal areas are facing many challenges. It was mentioned by Silva et al. (2014) that this important issue had not received much attention until the people realized that they were threatened economically, socially, and environmentally. At some point, coastal erosion is believed to pose a significant threat to the coastal population (Delgado-Fernandez et al., 2015).

eISSN: 2398-4287 @ 2020. The Authors. Published for AMER ABRA cE-Bs by e-International Publishing House, Ltd., UK. This is an open access article under the CC BYNC-ND license (http://creativecommons.org/licenses/by-nc-nd/4.0). Peer-review under responsibility of AMER (Association of Malaysian Environment-Behaviou Researchers), ABRA (Association of Behavioural Researchers on Asians) and cE-Bs (Centre for Environment-Behaviour Studies), Faculty of Architecture, Planning \& Surveying, Universiti Teknologi MARA, Malaysia.

DOI: https://doi.org/10.21834/e-bpj.v5i13.2053 


\subsection{Literature Review}

The coastal zone in Malaysia is seen as experiencing erosion due to many reasons, particularly from human activities. Coastal erosion in Malaysia first came to alertness at a national scale for more than 40 years ago (Ghazali, 2006). Coastal erosion is defined as the physical wearing of surface materials by wave action and tidal currents (Azid et al., 2015). In another study, Van Wesenbeeck et al. (2015) agreed that one of the reasons aquaculture production collapsed was due to coastal erosion. Despite this, the seaside community is considered as an essential group, especially in the reinforcement of the country's food security (Shaffril et al., 2015).

The current policies and practices for coastal zone management may not be sustainable (Brown, 2010; Haslett, 2009). He added that there should be a transformation of policy management and be accepted by the local communities to ensure its effectiveness (Brown, 2010). The need for design strategies in coastal areas should be a global agenda (Lee, 2015). Meanwhile, Asmawi (2012) claimed that the Malaysian coastal management strategies are not extensively incorporated into the land use planning system. Besides, there had not been a final coastal management plan at the state level in Peninsular Malaysia except for Penang, as well as the lack of reinforcement from the state government (Asmawi, 2012). Haslett (2009) believes that the numerous agencies with various interests involved in managing the coast cause administrative issue hence requires one specific body encompassing of overall responsibility for management planning.

Previous studies demonstrated that coastal areas in Malaysia needed attention (Harbitz et al., 2016; Jensen, Savioli, and Saaban, 2016; Azid et al., 2015; Shaffril et al., 2015; Pourebrahim, Hadipour and Mokhtar, 2015; Abdullah and Qing, 2015). However, those studies focused on separate purposes, therefore producing various outcomes. Lee (2010) realized that there appeared to be a lack of public support when solving coastal issues. Based on the continuing problems and the literature review, this study, therefore, aims at examining the local community's beliefs and role in protecting their coastal areas.

\subsection{Methodology}

A case study method is applied when the study is intended to study a community or a small group of people (Yin, 2014). The investigation deals principally on the site analysis and the current practice and mitigation process by the local authorities, as well as the public's inclination of involvement in coastal risk management programs.

\subsection{Scope and Limitation of Study}

This study is a social study that did not include engineering or mechanical measurements of coastal erosion. It concentrated on the perceived impacts of coastal erosion thorough site investigation. The Google Earth satellite images of coastal changes were not anticipated for the measurement of erosion degree. The researchers also had not included samples from outside of Mukim Jeram's areas since the purpose was to study the local community's perception.

\subsection{The Case Study: Pantai Remis and Pantai Jeram}

Pantai Remis $\left(3.2009^{\circ} \mathrm{N}, 101.3057^{\circ} \mathrm{E}\right)$ and Pantai Jeram (3.2253 $\left.\mathrm{N}, 101.3057^{\circ} \mathrm{E}\right)$ in Mukim Jeram, Kuala Selangor, Malaysia (Fig. 1) were selected as the case study based on their long experience of coastal erosion since the 1980s. Pantai Jeram (64.23 acres) and Pantai Remis (40.21 acres) are both connected in a long stretch of coastline. Historically, during the early 80 s, the scale of erosion was alarming, which even reached 4 meters of erosion a year.

\subsection{Data Collection}

Secondary data included current guidelines for coastal risk management in Malaysia and the mitigation plan by the Kuala Selangor local authorities. In contrast, the trends of coastal changes were captured from Google Earth from different years to examine the changes in the coastal landscape. Primary data was obtained through several techniques, namely; (1) Site Investigation; (2) Focus Group Discussion; and (3) Perception Survey.

A site investigation was carried out several times from 2018 to 2019 to examine the current condition of the area over time since the government progressively made recovery schemes throughout the two years. The Focus Group Discussion (FGD) was conducted on the $31^{\text {st }}$ of July 2019, involving 27 representatives from various local authorities and the local community. Participants were from the Kuala Selangor District Council, Selangor Water Management Board (known as Lembaga Urus Air Selangor or LUAS), Selangor Irrigation and Drainage Department and Kuala Selangor Irrigation and Drainage Department, and other technical departments.

A questionnaire survey (Perception Survey) was designed to examine the residents' perception and belief in coastal risk management. A non-probability sampling, using the Purposive Sampling, was employed. Plowright (2011) asserted that in nonprobability sampling, the selection of cases is based on a particular requirement, subject to the study aim, and not picked randomly. Lopez-Carresi et al. (2014) believed that the foremost people in protecting the environment from disasters are the local communities. The purposive sampling suits a smaller scale survey and is applied to gather representative samples (Bansal, 2017; Babbie, 2014; Taylor, Sinha, and Ghoshal, 2006). Sampling calculation suggested a total of 265 samples to represent 849 population of Pantai Remis and Pantai Jeram. However, only 212 respondents returned the forms. 


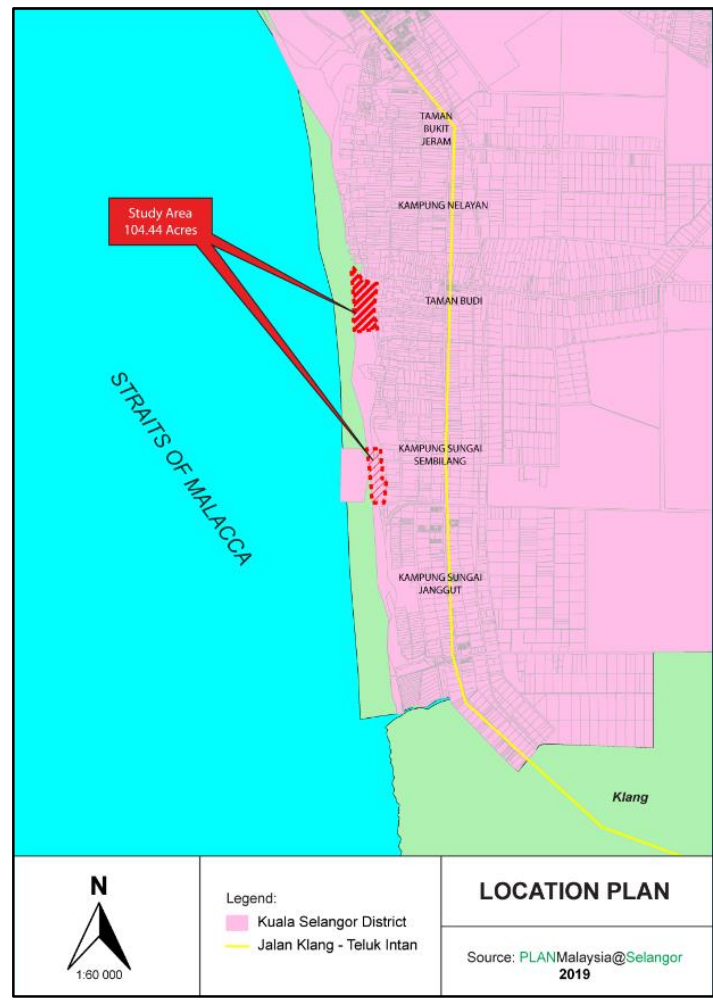

Fig. 1: Location Plan of Pantai Jeram and Pantai Remis in Kuala Selangor, Malaysia (Source:PLANMalaysia@Selangor, 2019)

\subsection{Results and Findings}

\subsection{Results from Site Investigation Analysis}

The coastal landscapes for both Pantai Remis and Pantai Jeram are filled with rock structure installed by the government to reduce impacts from erosion (Fig. 2). Some parts of the beaches, especially at Pantai Remis, are not user-friendly. Visitors cannot easily reach the seawater since the government built a 20-meter revetment rock along the coastline of Pantai Remis (Fig. 3) and a 10-meter revetment rock for Pantai Jeram (Fig. 4).

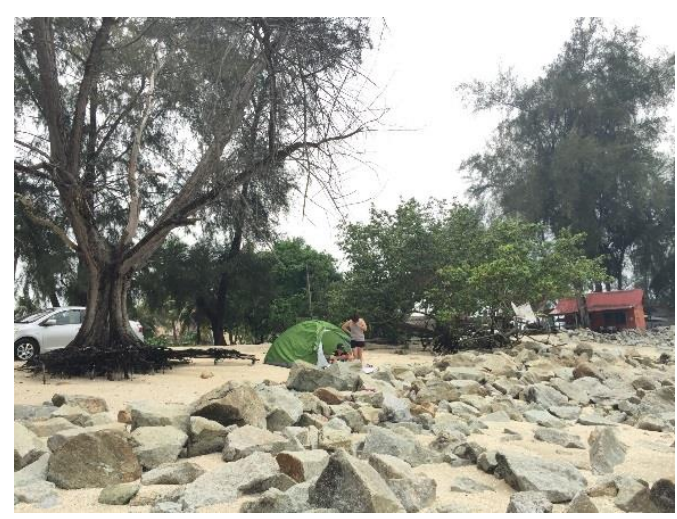

(a)

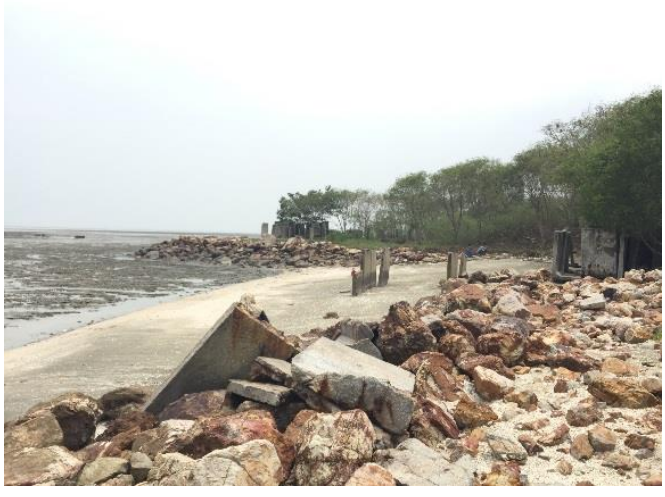

(b)

Fig. 2: (a) Rock revetment structure in Pantai Remis; (b) Rock revetment structure in Pantai Jeram 


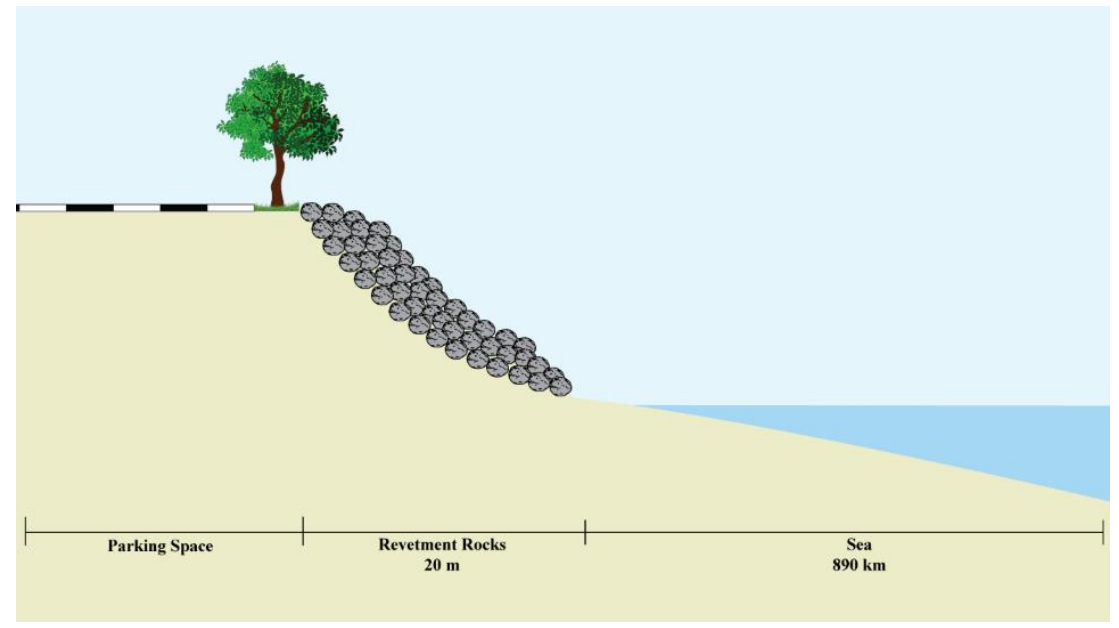

Fig. 3: Cross-section of Pantai Remis

(Source: Authors' Illustration Based on Site Investigation)

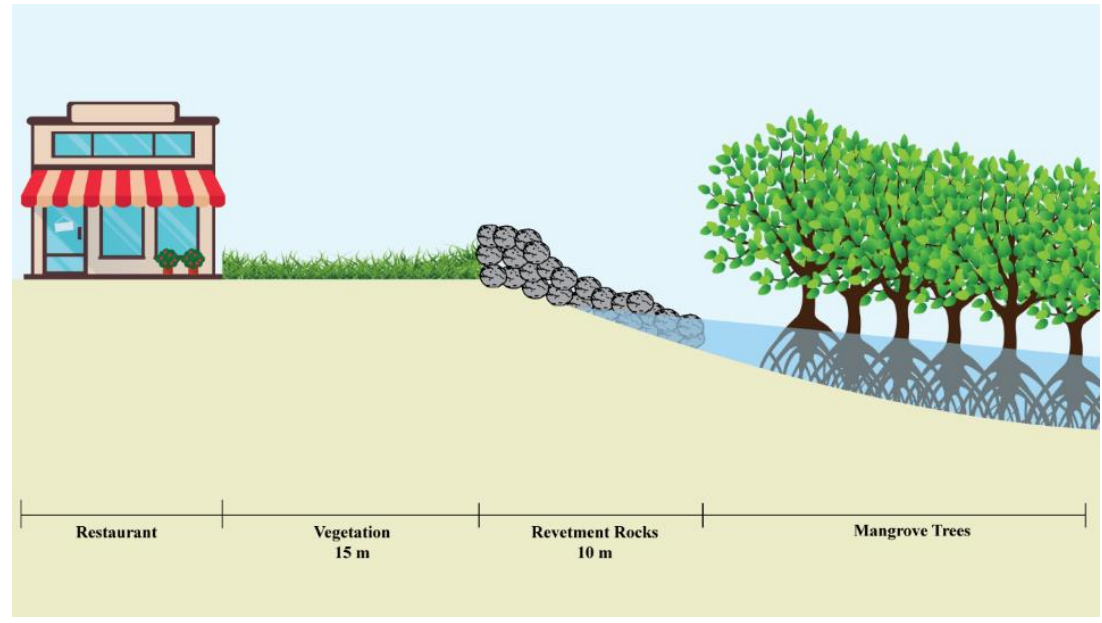

Fig. 4: Cross-section of Pantai Jeram

(Source: Authors' lllustration Based on Site Investigation)

Changes in activities and coastal environment were apparent from 2018 to 2019. In 2018 when the revetment wall was built, there were not many food operators and visitors. After the completion of the project, along with newly developed public facilities like additional public toilets, upgrading of the food court, an enhancement to landscape, and upgrading of parking space, more visitors were seen, especially at the weekends. Most visitors came during the daytime in Pantai Remis for recreational purposes (Fig. 5) while Pantai Jeram draws people in the evening when the seafood restaurants are open.

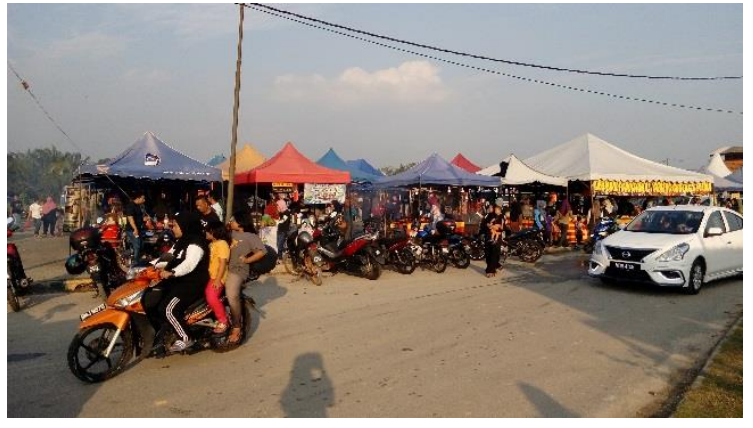

(a)

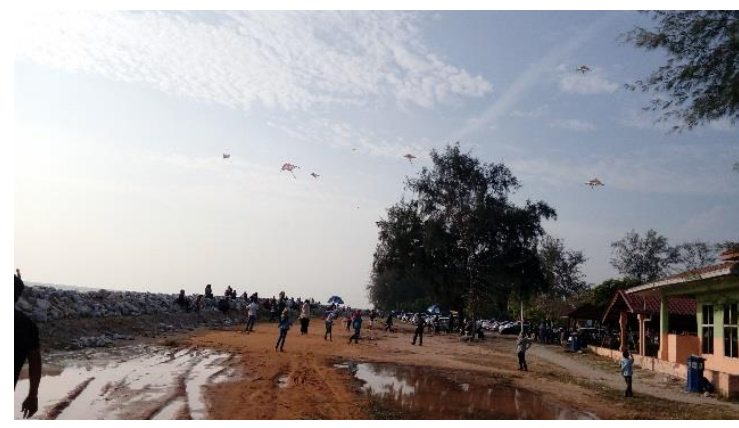

(b)

Fig. 5: (a) Business (food) operators attracting visitors to Pantai Remis; (b) Playing kites at Pantai Remis 
However, it concerned that there were two restaurants at Pantai Remis located close to the sea line, which poses danger to the owners and customers. According to PLANMalaysia (2012a; 2012b), any development along the coastline should be at a distance of at least 60 meters from the sea line. From the observation, these two restaurants are threatened by the waves and tides. Other than that, most permanent structures had considered the distance from the sea.

\subsection{Results from Coastal Changes Trend Analysis}

Results indicated that both coastal areas had narrow beaches and landscape changed over the years. Satellite images below show the differences of the coastal view for Pantai Remis from 2010 to 2018, showing the increased width of beach probably from engineering works (Fig. 6) and land use nearby also changed over the period. Changes were also apparent for Pantai Jeram, which displayed the diminishing mangroves along the coastline. In the year 2010, mangroves were seen scattered along the shore, but in 2017, mangroves were just available up north (Fig. 7).

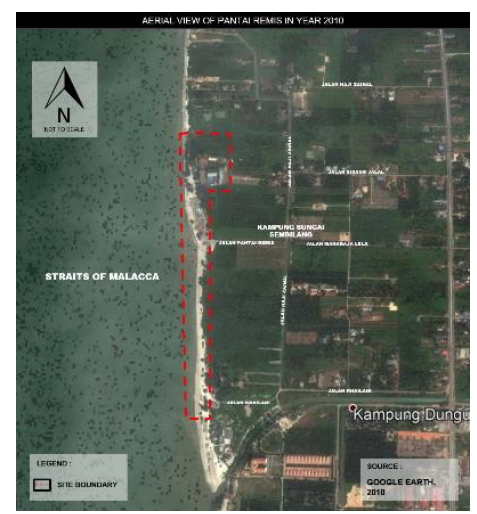

(a)

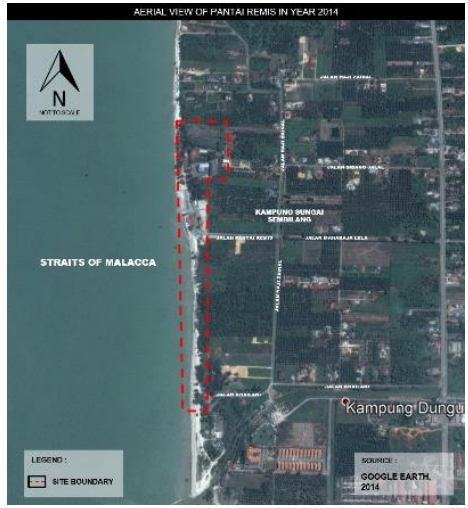

(b)

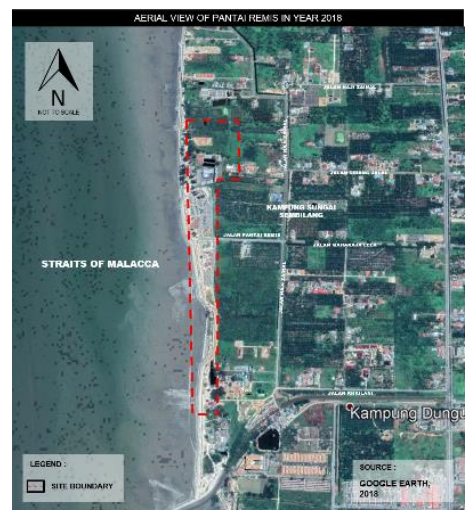

(c)

Fig. 6. (a) Eroded beach in 2010; (b) Beach became even narrow in 2014; (c) Beach has improved and became wider in 2018. (Source: Google Earth, 2010; 2014; 2018)

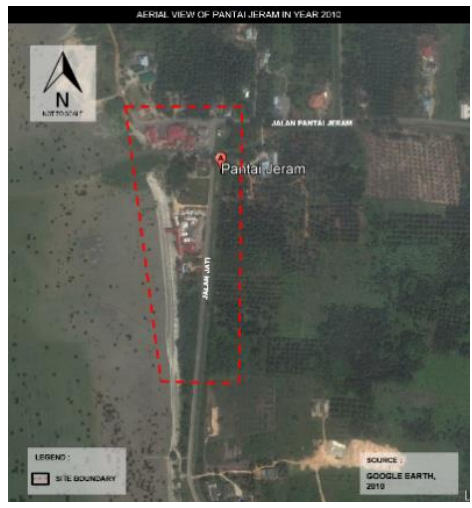

(a)

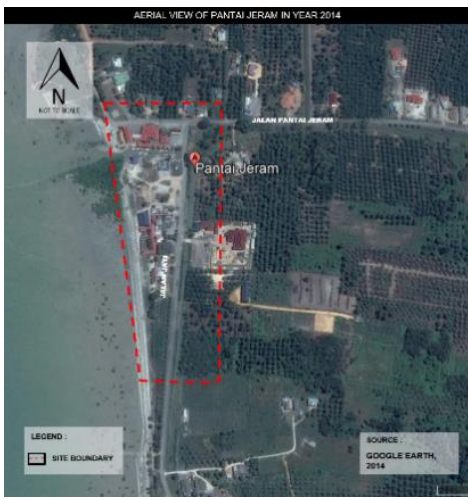

(b)

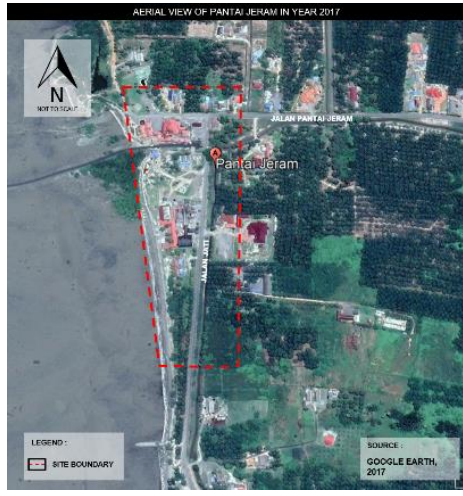

(c)

Fig. 7. (a) Mangroves were scattered in 2010; (b) Mangroves declined in 2014; (c) In 2017, mangroves concentrated at the north part only. (Source: Google Earth, 2010; 2014; 2017)

\subsection{Results from Focus Group Discussion (FGD)}

Results from the FGD indicated that there are many government agencies involved in managing and protecting the study areas. These include the Kuala Selangor District Council, Kuala Selangor Irrigation and Drainage Department, Selangor Irrigation and Drainage Department, Selangor Water Management Board (LUAS), PLANMalaysia@Selangor and other technical agencies. Each agency has its responsibilities; water pollution is under the obligation of LUAS, planning permission for development is in charge by the District Council, PLANMalaysia (2012a; 2012b) produces the guidelines for planning and development. Meanwhile, policies for development are monitored by the District Council. In short, there are various duties, and each agency looks after its part.

At present, there is no specific guideline for coastal planning for the study areas. The rules and regulations were outlined by the state and federal governments and must comply with the National Physical Plan for Coastal Zones. Since there are many socio-economic activities along the coastline, the activities are monitored and controlled by the authority's enforcement unit. Planning and development must comply with the existing guidelines and should adhere to the State Structure Plan and Kuala Selangor Local Plan. Therefore, zoning demarcation is enforced. 
Previously, numerous activities were carried out to create public awareness. Mangroves Planting is a yearly program, but the focus is not just for the study areas, instead of along the coastline of Kuala Selangor, which cannot guarantee that mangroves will flourish at the site. However, there beach cleaning-up programs are frequent at the site and are constantly organized by volunteers or private companies. Sometimes the District Council conducts law enforcement operations, and at times the Forestry Department helps to stop illegal shrimp farming.

A considerable sum of funding had been allocated to redevelop and maintain the coastal zones. According to the District Council, millions were spent to build the revetment rock and relocate local business operators, as well as upgrading the public facilities and infrastructure. Based on the FGD, the main issues of coastal risk management were the expensive recovery cost and sustaining the area to its best environmental state. Also, the residents were mentioned as part of coastal protection programs and participated in many activities like mangrove replanting, clean-up, and voluntary works.

\subsection{Results from Public Perception Survey}

The Perception Survey witnessed motivational responses from the local community of Pantai Remis and Pantai Jeram. The survey discovered that $90 \%$ of the total respondents are aware of the coastal erosion occurrence at their beaches. Moreover, when asked what the cause for the eroded beach was, $76 \%$ answered that the coastal erosion was caused by nature and natural process. This result informs that the local community is aware of the issue that their coastal areas are facing.

In terms of interest in protecting their beaches, the majority (69\%) were willing to contribute their time and energy to participate in coastal related activities. These residents expressed their attentiveness to participate when asked whether they are eager to join any coastal protection programs.

The survey also revealed that many residents (46\%) visit their beach almost every week, and reflected their positive attention towards the beach. Furthermore, when asked why they like to repeat their visits to the areas, $46 \%$ mentioned that they are there for recreational purposes.

The perception survey also saw a conflicting idea from the residents. The majority (84\%) do not want to be involved in mangrove planting but suggested that rock structure is better for coastal protection. Even so, most residents (64\%) expressed their optimistic belief that sustaining the coastal areas requires management and protection activities.

\subsection{Discussion and Recommendations}

The study indicated that Pantai Remis and Pantai Jeram are continuously facing coastal erosion since the coastal areas cannot avoid the natural occurrence of wind and waves. Both areas have long experienced coastal erosion since the early $80 \mathrm{~s}$, which affected the source of income of residents and the coastal landscape. Previous studies stressed that coastal areas needed attention. Various efforts were made to reduce the severe impacts of coastal erosion. An engineering attempt was carried out in 2018 to build a long stretch of revetment rock structure along the coastline, and the project was completed in 2019. With the funding from the government, Pantai Remis and Pantai Jeram were revitalized with new facilities and enhanced recreational image. However, the installment of revetment rock had undeniably affected the landscape and the sense of natural coastal environmental scenery. Nevertheless, the areas still receive many visitors, especially at the weekends, since the coastal areas offer many recreational activities. The locals can spend their family time there since the district council allows local entrepreneurs to operate their food stalls and market, which sells local sea produce. And as expected, the people of Pantai Remis and Pantai Jeram appeared to be motivated in supporting the government's effort in managing and protecting the coastal zone. They believe that the beaches are their assets and hope to see a lasting resource that can be enjoyed by their future generation.

Based on the results and findings of the study, several recommendations were formulated. Results indicated that were no specific guidance for the local community to participate in any community engagement programs in managing and protecting the coastal zones. Most recovery schemes and initiatives were customarily the government's tasks carried out by the local authorities and related agencies to coastal management. This conventional approach needs to change. Previous programs and coastal protection events were carried out by the government and non-governmental agencies but not as a time-scheduled basis. Programs were delivered according to the availability of funding, and most are voluntary efforts. Also, the coastal erosion events at the sites are naturally caused by winds, tides, and waves. Because of this, coastal risk management should be a continuous process but grounded by the findings from the public opinions' survey

\subsection{Research Outputs: A Guiding Principles for Local Authority and a Toolkit for Local Residents}

There were two (2) outputs produced from the study. The first is a Guiding Principles guidebook specifically designed for the local authority as a reference to manage and protect the coastal areas of Pantai Jeram and Pantai Remis (Fig. 8). The book is the first-ever guidebook for Pantai Jeram and Pantai Remis, which had obtained its ISBN (978-967-2340-09-6) from the National Library of Malaysia in January 2020. It can also be a reference to LUAS and the Kuala Selangor Irrigation and Drainage Department. The book contains a brief background of the past and current situation of the areas, and trends of coastal erosion. It also informs about the findings from the Public Perception Survey.

The second research output is a Toolkit for the local people of the site, which acts as a short manual for community engagement (Fig. 9). As mentioned earlier in the literature review section, the coastal community is an essential group. This booklet is the first booklet for the public ever produced. It is designed in the Malay language for easier knowledge-transfer to the local community. It had also received the ISBN (978-967-2340-10-2) from the National Library of Malaysia in January 2020. This booklet also informs about the background and current situation of Pantai Remis and Pantai Jeram. It conveys the knowledge of Sustainable Development Goals 
(SDGs) and the importance of protecting the coastal zone. The budget for programs was not specified, but the residents can seek capital or subsidy from the government or NGOs since many environmental-oriented organizations exist in Malaysia.

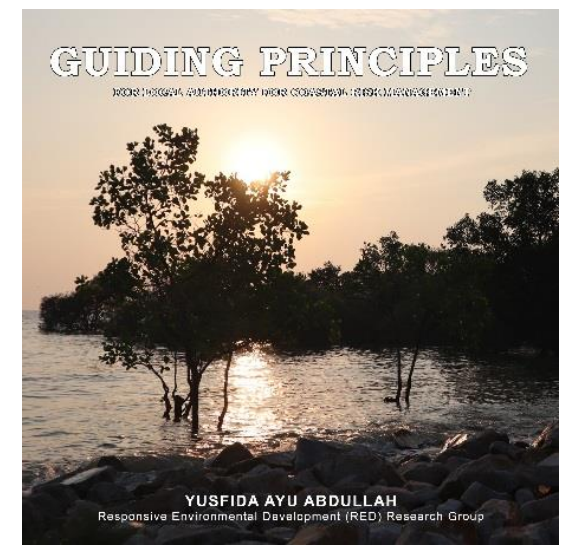

(a)

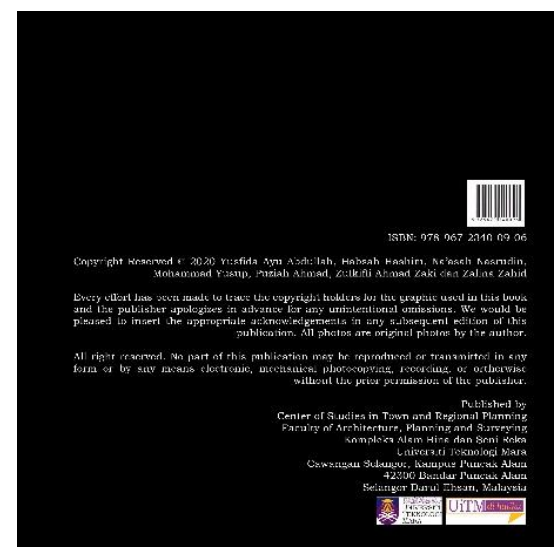

(b)

Fig. 8. (a) The cover of the Guiding Principles guidebook; (b) The copyright page with ISBN

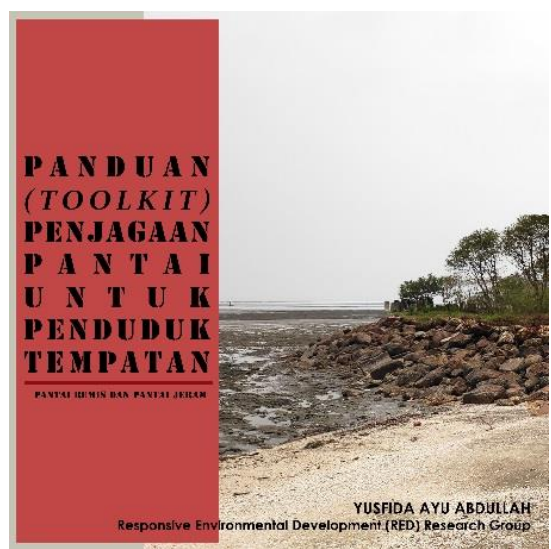

(a)

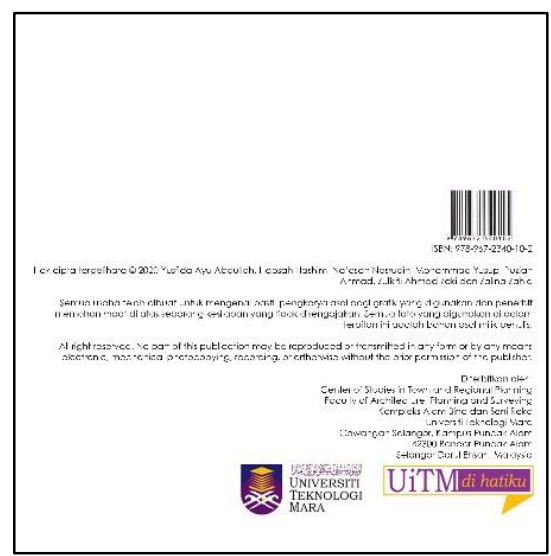

(b)

Fig. 9. (a) The cover of the Toolkit; (b) The copyright page with ISBN

\subsection{Recommendations}

This study had therefore proposed several general recommendations following the results of the study; (1) Short-term (immediate) actions; and (2) Long-term (continuous) efforts. The first category recommends urgent actions based on the condition of the study area. The second category requires a constant operation, which may help to sustain the coastline.

Short-term actions include a relocation program of two restaurants situated along the beach. These two shops operate daily and are threatened by the wave and high tide. To comply with the federal guideline of development along the coastline, these shops must be reallocated further from the sea line (to meet the $60 \mathrm{~m}$ distance guided by the PLANMalaysia's guidance). This action will ensure the safety of food operators, visitors, and the structure of the beach. However, this action will not stop coastal erosion since natural forces cause erosion, but it will ensure the safety of the operator and customers. The other suggestion is to organize timely-scheduled replanting and maintenance of mangroves and casuarina along the beaches, especially for Pantai Jeram. This program should be arranged at least twice a year because not all mangroves or casuarinas can hold the soil and continue to grow. Nevertheless, this requires efforts, funding, and contributions from stakeholders or government and the public.

The long-term efforts require continuous monitoring and measurement of coastal erosion. It may need engineering or technology to evaluate, capture, and record the trends. Systematic documentation will help future coastal risk management. Continuous effort in creating awareness of coastal protection among the public can be delivered through various public programs. Campaigns can be carried at public spaces or schools, and children are educated at school. At the same time, adults can be continuously reminded at their gathering locations, for example, at worship buildings during their religious events, or through the dissemination of information like pamphlets or brochures. Coastal Fair can be organized every year, which can attract more visitors, thus resulting in income to the business operators. The study also suggests a new guideline to coastal risk management for Kuala Selangor District Council to suit the local context and fit its local culture and lifestyle.

The authorities could improve their practice to coastal risk management by introducing community engagement initiatives rigorously for the areas. The authorities had put great efforts into saving the coastal areas but had not tried to include the public into decision- 
making. Through this study, it was captured that the beliefs and motivation of the residents in the events of coastal protection programs are essential too. However, there was a lack of inquiries or surveys for the residents asking for their opinions and needs.

\subsection{Conclusion}

This study highlights the coastal erosion issue in Pantai Remis and Pantai Jeram, which had experienced tremendous impacts from coastal erosion since the 1980s, which affected the coastal landscape and activities of the people living nearby the area, as well as the visitors. The researchers believe that the study had achieved the research goal and contributed to the body of knowledge through the research outputs. The researchers deemed this study as an added-value and useful product that can be a supplementary reference to the authorities and stakeholders, as well as furnishing the residents with a toolkit to participate in coastal management and protection programs. Future study may include the effectiveness of coastal erosion recovery schemes through engineering technology, or effects of revetment rock structure towards the coastal activities, or the role of NGOs, or even evaluate the effectiveness of community engagement initiatives. Finally, there is no ending to coastal risk management study since the sustainability of coastal zones relies very much on us as humans.

\section{Acknowledgements}

The authors would like to thank Universiti Teknologi Mara (UiTM) for funding this study under the REI Grant (Project Code: 600IRMI/MYRA 5/3/REI (004/2018). We also like to express our gratitude to the local authorities of Kuala Selangor (especially the Kuala Selangor District Council) and the FGD participants for their input and suggestions. Our appreciation also goes to the residents at Pantai Remis and Pantai Jeram for their participation. Finally, thank you to the UiTM Research Management Centre for managing this research project and to the Faculty of Architecture, Planning and Surveying for supporting the study.

\section{References}

Abdullah, L. and Qing, S.X. (2015), Quality of Life Among Coastal Population Using Weighted Geographic Information System: A Case of Setiu Wetlands, International Journal of Information Processing and Management (IJIPM), Vol. 6, Number 4, 2015.

Asmawi, M. Z. (2012), The Future of Coastal Management Programme in Malaysia: Making the Coast Visible to Planner, Journal of the Malaysian Institute of Planners, Vol. 10 (2012), pg.125-146.

Azid, A., Che Hasnam, C.N., Juahir, H., Amran, M.A., Toriman, M.E., Kamaruddin, M.K.A., Mohd Saudi, A.S., Gasim, M.B. and Mustafa, A.D. (2015), Coastal Erosion Measurement Along Tanjung Lumpur to Cherok Paloh, Pahang During the Northeast Monsoon Season, Jurnal Teknologi, 2015, pg.27-34.

Babbie, E (2014) The Basics of Social Research (6th edition). United States: Wadsworth Cengage Learning.

Bansal, A. (2017) Survey Sampling. Oxford: Alpha Science International Ltd.

Brown, I. (2010), Multi-Functional Assessment of Coastal Landscapes with Climate Change. In: Green, D.R. (ed.), Coastal and Marine Geospatial Technologies, Coastal Systems and Continental Margins, Vol. 13, pg.335-346.

Delgado-Fernandez, I., McBride, M., Platt, R. and Cameron, M. (2015), Sefton's Coast Vulnerability to Coastal Flooding Using DEM Data, North West Geography, Vol. 15, No. 1, 2015, pg.1-8.

Ghazali, N.H.M. (2006), Coastal Erosion and Reclamation in Malaysia, Aquatic Ecosystem Health \& Management, 9 (2), pg.237-247, DOI: 10.1080/14634980600721474.

Google Earth (2010) Satellite Images of Pantai Remis, Kuala Selangor, Malaysia.

Google Earth (2014) Satellite Images of Pantai Remis, Kuala Selangor, Malaysia.

Google Earth (2018) Satellite Images of Pantai Remis, Kuala Selangor, Malaysia.

Google Earth (2010) Satellite Images of Pantai Jeram, Kuala Selangor, Malaysia.

Google Earth (2014) Satellite Images of Pantai Jeram, Kuala Selangor, Malaysia.

Google Earth (2017) Satellite Images of Pantai Jeram, Kuala Selangor, Malaysia.

Haslett, S.K. (2009) (2nd Edition), Coastal Systems. Routledge, Taylor \& Francis Group: London.

Hashim, R., Kamali, B., Mohd Tamin, N. and Zakaria, R. (2010), An Integrated Approach to Coastal Rehabilitation: Mangrove Restoration in Sungai Haji Dorani, Malaysia, Estuarine, Coastal and Shelf Science 86 (2010) pg.118-124.

Harbitz, C.B, Kaiser, G., Glimsdal, S., Jaedicke, C., Vafeidis, A.T., Gothlich, S.E., Hoydal, O.A., Lovholt, F. and Nadim, F. (2016), Coastal Inundation, Multi-hazard Analysis for a Construction Site in Malaysia, International Journal of Risk Assessment and Management, Vol. 19, Nos. 1-2, 2016, pg.142-164.

Jensen, J.H., Savioli, J.C. and Saaban, K. (2016), The Impact of Wave Blocking from Ship Hulls on the Stability of Tg. Piai Coastline, International Journal of Environmental Science and Development, Vol. 7, 2016. 
Lee, O.A. (2010), Coastal Resort Development in Malaysia: A Review of Policy Use in the Pre-construction and Post-construction Phase, Ocean \& Coastal Management, 53 (2010), pg.439-446.

Lee, Y. (2015), Protecting the Coastline from the Effects of Climate Change: Adaptive Design for the Coastal Areas of Gangneung, Korea, Journal of Building Construction and Planning Research, 2015, 3, pg.107-115.

Lopez-Carresi, A., Forhham, M., Wisner, B. Kelman, I. and Gaillard, JC. (2014) (Eds.) Disaster Management. International Lessons in Risk Reduction, Response and Recovery. New York: Routledge.

PlanMalaysia (2012a). The National Coastal Zone Physical Plan (Jilid 1). Department of Town and Country Planning: Kuala Lumpur.

PlanMalaysia (2012b). The National Coastal Zone Physical Plan (Jilid 2). Department of Town and Country Planning: Kuala Lumpur.

PLANMalaysia@Selangor (2019) Map of Pantai Remis and Pantai Jeram, Kuala Selangor. Selangor: PLANMalaysia@Selangor.

Plowright, D. (2011) Using Mixed Methods: Frameworks for an Integrated Methodology. London: SAGE Publications, Ltd.

Pourebrahim, S., Hadipour, M. and Mokhtar, M. (2015), Impact Assessment of Rapid Development on Land Use Changes in Coastal Areas; Case of Kuala Langat District, Malaysia, Environ Dev Sustain, 17, pg.1003-1016.

Shaffril, H.A.M., D'Silva, J.L., Kamaruddin, N. and Omar, S.Z. (2015), The Coastal Community Awareness Towards the Climate Change in Malaysia, International Journal of Climate Change Strategies and Management, Vol. 7, No. 4, 2015, pg.516-533, DOI: 10.1108/IJCCSM-07-2014-0089.

Silva, R., Martinez, M. L., Hesp, P.A., Catalan, P., Osorio, A.F., Martell, R., Fossati, M., Da Silva, G.M., Marino-Tapia, I., Pereira, P., Cienguegos, R., Klein, A. and Govaere, G. (2014), Present anf Future Challenges of Coastal Erosion in Latin America, Journal of Coastal Research, Special Issue No. 71, 2015, pg. 1-16.

Taylor, B., Sinha, G. and Ghoshal, T. (2006) Research Methodology: A Guide for Researchers in Management and Social Sciences. India: Prentice-Hall.

Van Rijn, L.C. (2011), Coastal Erosion and Control, Ocean \& Coastal Management, 54 (2011), pg.867-887.

Van Wesenbeeck, B.K., Balke, T., Van Eijk, P., Siry, H.Y., Tonneijck, F., Rudianto, M.E. and Winterwerp, J.C. (2015), Aquaculture Induced Erosion of Tropical Coastlines Throws Coastal Communities Back into Poverty, Ocean \& Coastal Management, 116 (2015), pg.466-469.

Yin, R.K. (2014) Case Study Research. Design and Methods. London: SAGE Publications Ltd. 